\title{
Remedies for Discrimination in Apprenticeship Programs
}

EFFORTS BY Negroes to gain admission to apprenticeship programs in the building, machinist, and printing crafts have received widespread attention. Street demonstrations, picketing, entrance blocking, "sleepins" in union halls, and several violent clashes with police have catapulted the topic into the headlines. Accordingly, the issue has joined the grievances which serve as rallying cries for civil rights spokesmen in every section of the country. ${ }^{1}$

In response both to the public furor and to the notable absence of Negro workers in these trades, public authorities have adopted a variety of remedial measures. The main objective of this article is to review the effectiveness of these remedies and to suggest others which are likely to be more successful in solving this important domestic problem.

Our conclusions are based on the findings of a study we conducted in 1966 for the U.S. Department of Labor on Negro participation in apprenticeship programs. ${ }^{2}$ Ten cities, each with a large Negro population, were surveyed; they were selected to illustrate a variety of problems and remedial programs, as well as to be geographically representative. ${ }^{3}$ Comparisons were made with the year 1963, which represents a benchmark for measuring prog-

* Professor and Assistant Professor of Economics, respectively, University of Texas.

1 Our findings confirm the virtual absence of Negroes from many apprentice programs, in spite of significant breakthroughs in some major cities like New York. The 1960 Census reported that nonwhites constituted 2.52 per cent of all apprentices and that there were only 2,191 nonwhite apprentices in the country; there were only 79 nonwhite electrical apprentices and 62 nonwhite apprentices in the plumbers' and pipefitters' trades. Although it is difficult to believe that these figures are accurate, the fewness of Negro apprentices has been confirmed by many other studies. See, for example, George Strauss and Sidney Ingerman, "Public Policy and Discrimination in Apprenticeship," Hastings Law Journal, XVI (February, 1965), 285.

2 F. Ray Marshall and Vernon M. Briggs, Jr., Negro Participation in Apprenticeship Programs, a Report to the Office of Manpower Policy, Evaluation, and Research, U.S. Department of Labor (December, 1966). A book based on this report, The Negro and Apprenticeship, will be published by the Johns Hopkins University Press in 1967.

3 The cities were New York, Philadelphia, Washington, D.C., Pittsburgh, Cincinnati, Cleveland, Detroit, Atlanta, Houston, and San Francisco-Oakland. 
ress in the area of job opportunities. Previously there were almost no Negroes in the major apprenticeable trades (electricians, plumbers, pipefitters, ironworkers, sheet metal workers, machinists, or typographers) in our 10 survey cities. A lone exception was the 1962 class of Local 3 of the International Brotherhood of Electrical Workers in New York City. ${ }^{4}$ Since 1963, in all the survey cities, except Atlanta and Houston, most major apprenticeship programs have admitted a few Negroes. The present small number, however, can only be described as token progress.

In order to put our conclusions in proper perspective, some observations must be made at the outset. In the first place, apprenticeship training is not quantitatively a very important means of improving Negro employment patterns. Barring an expansion in the total number of apprentices, not more than 3,000 Negroes in the nation are likely to get jobs each year in the skilled trades by completing apprentice programs. Qualitatively, however, apprenticeship is important to Negroes because it is the main (and sometimes the only) way to get into some trades in particular cities. Furthermore, we were surprised at the extent to which apprenticeship programs seem to be preparing future supervisory personnel in many occupations.

It should also be emphasized that many of our remarks apply to all disadvantaged groups, and not just to Negroes. We have concentrated on Negroes because we were asked to study them. We think, however, that the aim of public policy should be to increase the opportunities of all disadvantaged youths, and therefore hope that our suggestions will be applied to many other groups.

\section{Nondiscrimination Policies}

Federal and state apprenticeship regulations. The basic federal law establishing apprenticeship policy is the National Apprenticeship (Fitzgerald) Act of 1937. The statute is administered by the Bureau of Apprenticeship and Training (BAT) of the U.S. Department of Labor. Although BAT has offices in every state, its administrative powers are complicated by the fact that 30 states have their own apprenticeship statutes administered by respective state apprenticeship councils (SAC's). ${ }^{5}$ Specific minimum standards are set forth under the federal and state statutes. An apprenticeship program can be registered by BAT if its specific require-

${ }^{4}$ As a part of the bargaining agreement signed that year, the local union won the 25-hour work week with the stipulation that it depart from its nepotistic admission pattern of the past and admit a number of minority youths to its apprenticeship program. Subsequently 250 Negroes and 60 Puerto Ricans were taken in without being subjected to any qualification examinations.

5 Of the 10 survey cities, New York, Philadelphia, Pittsburgh, Cinncinati, Cleveland, and San Francisco-Oakland are in SAC states. 
ments comply with the relevant federal minimum standard. As of October 1966, there were 40,437 federally registered programs in the United States, of which 31,157 were in the SAC states.

In 1963, Secretary of Labor W. Willard Wirtz, over the heated objec. tions of some union spokesmen, approved new federal standards that re. quired that apprentices be selected on a nondiscriminatory basis. ${ }^{6}$ All pro. grams registered are required to select participants on the basis of "quali. fications alone," to use "objective standards," to keep "adequate records of the selection process" and to provide "full and fair opportunity for application." Any program established before January 17, 1964, which does not wish to select on the basis of qualifications alone can comply with the regulations by either selecting from existing employees or "demonstrating equality of opportunity" in their selection procedures. These alternative requirements apparently permit program sponsors to discriminate in favor of relatives or friends provided they also discriminate in favor of enough Negroes to gain the approval of the BAT Administrator. New programs do not have the option of demonstrating nondiscrimination or selecting from existing employees. They must use objective standards as the sole criteria for selection. ${ }^{7}$

In addition, the BAT is required to review all federally registered programs to guarantee conformance with the regulations. If a program is not in conformity and satisfactory action is not taken to bring about compliance, the program can be deregistered. On February 24, 1967, BAT issued a directive that any apprenticeship program in the $30 \mathrm{BAT}$ supervised states that is not in compliance with the federal nondiscrimination standards by March 10,1967 , will be subjected to deregistration proceedings. In the SAC states, each apprenticeship program is required to adopt standards consistent with the Secretary's regulations or the state runs the risk of having federal recognition withdrawn from all of its registered programs.

Within 18 months after the issuance of the equal opportunity measures, all state programs were approved. In addition, almost all of the joint apprenticeship committees (JAC's) which actually administer the specific programs within each jurisdiction have come into compliance.

It would be surprising, however, if any program failed to comply with the federal regulations, since it is possible to be in compliance and continue to bar Negroes through the use of selection procedures. The BAT insists that the selection procedures be objective, but it has left the determination of qualifications and the content and evaluation of the written and oral tests

629 CFR Part 30.

7 The New York printing industry is an example of a program that uses this selection system. 
to the respective JAC's. In addition, the apprentice sponsors apparently have been able to comply with the standards merely by giving formal written notice that they intend to comply. Such is clearly the case in Atlanta where every JAC is in compliance, yet there are no Negro apprentices in any major program.

Deregistration, the BAT's main weapon in dealing with registered programs, is regarded as more of an inconvenience to apprentice sponsors than a serious deterrent to traditional practices. Many employers appear to have no interest in supporting apprentice programs because they do not wish either to maintain craft identity or to incur the expense of training craftsmen who might leave for more desirable jobs elsewhere. The following advantages to be derived from registration of an apprentice program are clearly of much more interest to the construction and printing industries than to others.

1. Although little use is apparently made of federal and state minimum wage regulations, they permit registered apprentices to be paid less than the minimum wage. More important, the Davis-Bacon Act of 1931 provides for the establishment of prevailing wages on federal construction projects and allows apprentices to be paid less than journeymen. If a program loses its registration, apprentices must be paid journeymen rates.

2. Another advantage is the recognition which the certificate of completion bestows on the journeyman. The graduate of a registered apprentice program has a passport to employment in several job markets because of the minimum standards to which his certificate of completion attests.

3. Although military deferment presumably can be granted to apprentices in nonregistered programs, registered apprentices are automatically eligible for deferment.

4. There are other advantages to registration. In Detroit, for example, only registered programs are permitted to use the public schools for related training purposes.

The BAT's ability to get Negroes into apprentice programs would be very limited even if it had the power to compel compliance with the 1964 apprentice standards. Although many civil rights leaders felt that the regulations would be potent weapons to get Negroes into apprenticeship training, it soon became obvious that the use of tests and objective standards sometimes actually provided apprenticeship sponsors with a means for perpetuating discrimination. Without special preparation Negroes do not fare as well as whites on written examinations and, therefore, are more likely to get into apprenticeship programs where standards are flexible and no tests are required.

Although federal and state nondiscrimination regulations have engen- 
dered much dissatisfaction, they have not been completely ineffective. The fights over the implementation of the requirements have had important educational effects for all parties involved. A climate of opinion that changes are inevitable has been established. In this way, the regulations have served to create attitudes that are more conducive to change.

$B A T$ staff. It is widely believed that a major deterrent to the implementation of the nondiscrimination standards is the fact that BAT and the state apprenticeship agencies are not really sympathetic to enforcement. It is argued that BAT is staffed largely by former trade unionists who consider themselves "fronts" for the unions rather than agents to carry out nondiscrimination policies. Moreover, it is alleged that many of the apprenticeship agencies consider nondiscrimination policies to be inconsistent with their primary function of promoting apprenticeship programs.

The BAT also has been criticized for employing too few Negroes on its staff. ${ }^{8}$ The Bureau has met this charge by adding a number of specialists whose function is to assist Negroes to gain access to apprenticeship opportunities. These consultants are known as industrial training advisers (ITA's). From our work, it is clear that the ITA's have not been successful. Indeed, the Deputy Administrator of BAT told us in December 1965 that he did not know of a single instance where an ITA had been responsible for getting a Negro into an apprentice program. A major problem seems to be a lack of support by BAT regional staffs. Regional directors too often seem to resent the ITA's or think they are unnecessary. Accordingly, the directors have not typically given them sufficient independence or resources with which to operate.

The Civil Rights Act of 1964. Title VI of the Act prohibits the use of federal funds to support a discriminatory activity. This, accordingly, makes it unlawful for federal funds to be used to support any training for apprenticeship programs in public schools if discrimination is practiced in the selection of students. While not an insignificant restriction, the title is limited by the fact that many apprenticeship sponsors provide their own related instruction and others would do so rather than submit to what they consider to be onerous intervention.

Title VII of the Act declares it is an unfair employment practice for a union to exclude, segregate, or classify, or attempt to cause an employer to discriminate against any individual because of his race, color, religion, sex, or national origin. Employers likewise are prohibited from discriminating in any employment matter for racial reasons. Thus, JAC's are prohibited from discriminating in any apprenticeship training program.

8 Reports on Apprenticeship, U.S. Civil Rights Commission (Washington, D.C.: 1964). 
Title VII also authorizes the Attorney General to initiate civil actions in the federal courts when he has "reasonable cause to believe that any person or group of persons is engaged in a pattern or practice of resistance to the full enjoyment of any of the rights" secured by the title. The first suit filed under this section was against the St. Louis Building and Construction Trades Council, which was alleged to have interfered with a nondiscrimination agreement between the United States and a building contractor. The unions had walked off the job in protest against the hiring of a Negro plumbing contractor and his employees who belonged to an integrated union not affiliated with the AFL-CIO. The charge of discrimination was dismissed by the courts, although a charge that alleged patterns of discrimination existed is still pending.

The National Labor Relations Board. The NLRB, due largely to the refusal of Congress to extend its specific authority to deal with racial discrimination, has traditionally remained aloof from the employment discrimination issue. Departing from the past in 1964, the Board held in the .low famous Hughes Tool case that a violation of the duty of fair representation is also an unfair labor practice. ${ }^{9}$ The case was instigated by a Negro in Houston who had been unsuccessful in his attempt to gain admission into an apprentice program at the Hughes Tool Company, whose workers were represented by an independent metal workers union. In a 3-2 vote, the NLRB declared the union's action in failing to press the Negro's apprenticeship application to be an unfair labor practice and rescinded certification. The union was subsequently replaced by a local of the United Steel Workers and the Negro successfully passed the apprenticeship examination and has been admitted to the program. The Hughes Tool decision was not appealed, but if the enunciated doctrine is sustained in other cases it will mean that the aggrieved person has an administrative remedy for the duty of fair representation and it will no longer be necessary for him to seek relief in lengthy and costly court proceedings. Doubt is cast on the Hughes Tool doctrine, however, by the failure of a U.S. Circuit Court to support a similar ruling in a nonracial case involving the Miranda Fuel Company, ${ }^{10}$ and the Board's tradition of limiting the penalty for failing the duty of fair representation to revocation of a union's certification.

In a 1965 case, the NLRB held, in a complaint against the Plumbers Local 2 in New York City, that in no instance may union membership be a condition of employment prior to the expiration of the seven-day grace period allowed by the National Labor Relations Act (after which time the

9147 NLRB 1573 (1964).

10 NLRB y. Miranda Fuel Co., enforcement denied, 326 F.2d 172 (2d Cir. 1963). 
union may admit the applicant or else he can remain on the job as a nonunion employee). Moreover, the Board held that the standards for judging competency for admission to the union cannot be limited to the passing of a particular union's test. ${ }^{11}$ The decision grew out of the refusal of union plumbers to work with nonunion Negroes and Puerto Ricans who had been placed on a city construction project as the result of an agreement between the City Commission on Human Rights and a private contractor. The Local 2 decision was heralded by a NAACP spokesman as "a real breakthrough against discriminatory practices of unions." 12

Presidential committees. The function of the President's Committee on Equal Employment Opportunity (PCEEO), established in 1961, was to enforce nondiscrimination on private construction projects where federal funds were being used. Although PCEEO had no power to deal directly with unions (since they are not signatories to government contracts), it adopted a number of measures designed to combat racism by unions. The PCEEO could hold hearings with respect to the practices of any labor organizations, issue recommendations for remedial action, require employers to request nondiscrimination statements from unions, and elicit promises that unions would cooperate toward the achievement of the goal of equal opportunity. The PCEEO held that observance of BAT regulations would be required for compliance.

While the Committee did yeoman's duty in gathering data, there were few instances in which Negroes gained access to apprenticeship programs through its activities. In 1965 PCEEO was abolished: its federal employment activities were transferred to the Civil Service Commission and its contract compliance activities to the U.S. Department of Labor. It was felt that many of the Committee's former functions could be better performed by the newly created Equal Employment Opportunity Commission.

\section{State and Local Regulations}

Several states have passed special statutes to combat discrimination in apprenticeship. In New York, for example, such a law was adopted in 1964, following a series of demonstrations against alleged racial discrimination in construction projects and a court case involving discrimination in apprenticeship by Sheet Metal Workers' Local 28 of New York City. The New York regulations provide less latitude to the industry than the 1964 federal regulations. The New York law requires the selection of apprentices "after full and fair opportunity for application on the basis of

11152 NLRB 1093 ( 1965 ).

12 New York Times, June 6, 1965. 
qualifications not based upon race . . in accordance with objective standards which permit review." Under the federal regulations, no control is exercised over selection standards so long as they are objectively administered, but the New York regulations provide that "No program may be or remain registered unless it includes an acceptable selection procedure and acceptable standards for admission."

The New York law also specifies that to be acceptable a test must be reasonable, meaning that it is "reasonably related to general intelligence and/or job aptitude and is developed and administered by competent organizations." In addition, the law requires apprentice sponsors to give applicants written statements of qualifications for admission and specify in writing the reasons why applicants are not appointed. Any applicant who is rejected must be notified that he may register a complaint with the New York State Commission for Human Rights (NYSCHR) "if he believes that his failure to qualify on the applicant list, or his ranking on such list, or his failure of appointment was caused by discrimination. . .."

The penalty under the New York law is limited to deregistration. Program sponsors may have a hearing before programs are deregistered except where the NYSCHR has found discrimination, in which case the program may be deregistered without a hearing.

\section{State and Local FEP Commissions}

With the exception of Houston and Atlanta, all the cities surveyed have state and city fair employment practices acts (or their equivalents) and municipal human relations commissions charged with the responsibility of enforcing the local nondiscrimination statutes. In most instances, the city commissions are supplemented by the activities of counterpart state agencies. Needless to say, the apprenticeship question has been a common item on the agenda of most of these public bodies.

Of note, however, is the fact that few formal complaints alleging individual acts of discrimination have been filed. In New York, the state with the oldest law and the most active state commission, only three apprenticeship cases were filed between 1946 and 1967. The expense to the plaintiff, the length of the procedures, and the difficulty of proving that one was actually discriminated against have served to discourage recourse to such legal channels for redress. Furthermore, few Negro youths actually apply to apprenticeship programs and even fewer are aware that they have the right of appeal. These are added reasons for the limited effectiveness of antidiscrimination legislation in getting Negroes into apprenticeship programs. At the same time, however, the paucity of complaints filed under these state 
laws has strengthened the conviction of apprenticeship officials that the issue of discrimination has been exaggerated.

Because of the difficulties involved in the individual case approach, most of the investigations undertaken have concentrated on discrimination in specific apprenticeship programs. Findings have been made by the New York State Commission Against Discrimination (now the NYSCHR) in 1964 against Sheet Metal Workers Local 28 in New York City, by the Pennsylvania Human Relations Commission in 1963 against five construction unions in Pittsburgh, and by the Ohio Civil Rights Commission in 1966 against the building trades in general in Cincinnati. City commissions have ruled themselves or have been involved in court cases which condemned the practices of involved unions in Cleveland in 1955 against IBEW Local 38; in Philadelphia in 1963 against Plumbers Local 690, Steamfitters Local 420, IBEW Local 98, Sheet Metal Workers Local 19, Roofers Local 30, and IBEW Local 126; and in Pittsburgh in 1965 against Plumbers Local 29.

Many of the bodies mentioned above, plus the city commission in New York and the state commission in California, have held public hearings on the apprenticeship issue. An Ironworkers' program in Philadelphia in 1963 and an Electricians' program in Detroit in 1963 were denied the use of the public school facilities by boards of education for discriminatory reasons. Contracts for municipal construction projects were suspended in Philadelphia and New York City in 1963. Likewise, in Philadelphia in 1963 three contractors were told that they would have their city contracts revoked if they did not comply with the city's nondiscrimination ordinance.

\section{Apprenticeship Information Centers}

One reason why there are so few Negroes in apprenticeship is that few Negro youth are aware of the existence of these programs or how to apply for them. Our studies indicate that this lack of information is perpetuated by high school and employment counselors who, perhaps realistically in the past, have not advised Negro youngsters to interest themselves in apprenticeship training. Lacking family connections in the skilled trades, it is not surprising that Negro youngsters are poorly informed.

Although city apprenticeship information centers had already been established in California and New York City, the first federal center was opened June 17, 1963, in Washington, D.C., as a cooperative effort between the District of Columbia Apprenticeship Council, the District Commissioners, local school authorities, the U.S. Employment Service, and the U.S. Department of Labor. ${ }^{13}$ The operation of the centers was placed under the joint

13 "Expanding Apprenticeship for All Americans," American Federationist, July, 1963. 
control of BAT and the Bureau of Employment Security (BES). In spite of continued opposition from the construction industry, the Labor Department had succeeded in funding Apprenticeship Information Centers in 24 cities by the end of August 1966.

In order to promote the AIC's, teams from the BAT and BES have gone into various communities to explain the purposes of the centers and to overcome opposition. Special efforts have been made to overcome fears in the labor movement that the AIC's would usurp the unions' right to determine qualifications for their own programs. Much labor opposition arose over the stipulation that "The Centers shall examine the qualifications of applicants by interviewing, counseling, and testing, and refer only those qualified to available apprenticeship openings" (emphasis added). BES Administrator Robert C. Goodwin issued a letter of clarification on March 11, 1964, which called on all state employment security agencies to

Please notify the affected labor organizations and major apprenticeship sponsors ... that there is no intent on the part of apprenticeship information centers to bypass or disrupt the traditional perogative and authority of joint apprenticeship committees or other apprenticeship sponsors to make the final selection and placement of apprentice applicants.

Goodwin's clarification did not, however, allay the suspicions of industry spokesmen, many of whom were interviewed for this study and expressed the fear that the AIC's were simply the beginning of federal control of the apprentice selection process.

It is, of course, very difficult to establish criteria by which to evaluate the AIC's. Obviously, the most important objective of their activities is to get youngsters in general and minorities in particular into apprenticeship programs. We cannot, however, use this as our sole criterion, because the AIC's main function is to supply information and to act as a clearing house; it has no power to compel apprenticeship sponsors to accept their referrals. Obviously, therefore, the AIC's success depends in large measure on the cooperation of the apprenticeship establishment (sponsors and specialized government agencies), as well as on the imagination and effectiveness of the centers' staffs in recruiting, screening, referring, and getting applicants accepted into these programs.

The most successful AIC we studied was in Washington, D.C. The center's relative success seems to be due to a number of factors: the director is in charge of both the AIC and the Youth Opportunity Center and has good contacts with the labor movement; much of the work done by the unions in the Washington area is on government contracts; there is a large Negro community in Washington which has become involved in the cen- 
ter's operations; and the center does not have to contend with all the problems involved in a joint federal-state arrangement.

Between June 17, 1963, and June 17, 1966, the Washington AIC had 5,522 applicants, 72 per cent of whom were Negroes. Of those who applied, 1,868 were qualified by the AIC for apprenticeship programs; 1,214 or 65 per cent of these were Negroes. Of those who were qualified by the AIC, 1,679 were referred to unions; 1,150 of these (68 per cent) were Negroes. Of the total referrees, there were 609 placements; 403 Negroes $(66$ per cent) were placed.

Although we have no information on the occupational breakdown of the placements, the Washington experience apparently was more productive than any other city, with the possible exception of Chicago. At the time of the survey, the AIC's in most of our study cities had been relatively less successful in placing apprentices, white or nonwhite, and some of them appeared to be making little effort to publicize apprentice programs. In Oakland, the director of the AIC (which was not financially supported by the federal government) had been given the direction of the center without guidelines on how to operate it. During its first six months, the Oakland AIC had 357 applicants, 167 of whom were Negroes; it referred 75 applicants to apprentice programs, 30 of whom were Negroes. However, over half the Negroes were referred as a result of special recruitment to satisfy a request for Boilermakers. Of those referred, only 10, four of whom were Negroes, were accepted by the JAC's. Three of the Negroes were accepted by the Boilermakers and a fourth by the Automobile Painters.

The federally supported AIC's in Cleveland and Cincinnati have been no more successful than that in Oakland. The Director of the Cincinnati Urban League reported to us that the AIC there "has been a very regretful experience." Similarly, the executive director of the Citizen's Committee of Youth in Cincinnati lamented that:

The AIC is very uncooperative and inefficient. The AIC needs to be removed from the Employment Service System. It should be placed under another agency. ... For one thing the AIC does not do follow-up studies, this is one fault we would correct immediately.

The director of job development of the Pittsburgh Urban League told us that "an AIC is not the answer to the apprenticeship problem because it only goes through the motions." In Cleveland, the AIC has been relatively ineffective and does not have the respect of the Negro community or civil rights agencies. An inspecting team in November 1965 found that the Cleveland AIC had placed three Negro apprentices since December 1964-two auto mechanics and one tool-and-die maker. A spokesman for the Cleve- 
land Community Relations Board who served on the AIC Advisory Committee told us that the idea for the center had originated with community organizations, but that a local official of BAT had controlled the selection of the center's director-only one candidate was proposed for the job and he was present at the meeting when he was nominated.

Our evidence indicates that for a number of reasons some of the AIC's have not lived up to expectations. A major obstacle has been opposition from the building trades unions and at least some BAT officials. Also, unimaginative personnel have been put in charge of some of the centers. These facts are not unrelated, of course, because it is often possible to frustrate a program by seeing that it is incompetently or inadequately staffed. But the main reason for the centers' ineffectiveness is that they can do very little to supply applicants to apprentice programs unless they have adequate information about openings, and this can be got only from the JAC's. The JAC's cooperation is also needed to verify the results of referrals. Our evidence indicates that even with JAC cooperation there would not be many qualified Negro applicants, but it should be a function of the AIC's to locate such applicants and to keep the Negro community informed on apprenticeship opportunities.

\section{Preapprenticeship Programs}

The word "preapprenticeship" evokes varied reactionsfrom ringing endorsement to thundering opposition. One union interviewee claimed, approvingly, that it is "an answer to a major social problem"; another, an official of the AFL-CIO, warned us to avoid any reference to the term in our interview work.

The object of a preapprenticeship program is primarily to equip disadvantaged youths with the knowledge and experience necessary to compete for apprenticeship openings. In most instances, the enrollees in these programs lack the high school diplomas required for an apprentice position; in other cases they have graduated from substandard schools and cannot compete in written examinations with those from more fortunate backgrounds. Most of the enrollees are unemployed at the time of admission. In the case of those programs which have been most successful, applicants are carefully screened to select those with the aptitude and desire to learn. Since the Negro school dropout and unemployment rates far exceed those of whites, it is not surprising that the majority of the preapprentice enrollees have been Negro.

The goals and problems of preapprenticeship can be seen in the experiences of the National Institute of Labor Education (NILE). NILE entered 
into a contract with the Office of Manpower, Automation, and Training (OMAT) "to establish pre-apprenticeship, institutional and on-the-job training programs for unemployed youths formerly unable to qualify." 14 To overcome an early criticism of preapprentice programs-that they are apt to fragment a trade-the NILE programs were tied directly to continuing apprenticeship programs. Accordingly, graduates were assured of jobs as apprentices.

The NILE program was supported initially by Neil Haggerty of the AFL-CIO. But shortly after the Construction Industry Joint Conference gave its approval to the program as a model project for providing training opportunities for a large number of school dropouts, several building trades unions became very critical of the program. One union charged that the project was "injurious to the apprenticeship system." ${ }^{15}$ It then became increasingly difficult for the NILE programs to gain acceptance. Local BAT officials joined in the opposition. NILE attributes organized labor's veto of its efforts to (1) lack of official labor movement endorsement, (2) organized labor's growing distrust of all MDTA programs, (3) labor's sensitivity to outside intrusion, (4) journeymen's fears that admission of school dropouts would lower the prestige of their trade, and (5) the view of some union (and employer) officials that "school dropouts were no-good, ignorant and delinquent youngsters who had only themselves to blame for their lot, and who lacked the will and ability to learn a trade." 16

NILE also concluded that the "small employer views apprenticeship training as a method of training journeymen craftsmen, whereas the big employer uses apprenticeships for training foremen and supervisors." ${ }^{17}$ Since large employers apparently could not visualize a disadvantaged youth becoming a foreman, only the small employers were interested in the program. In addition, there was opposition from some BAT officials, who felt the program was an intrusion into their domain, and from some local vocational education officials, who resented attempted alterations in established procedures. In any event, the project received little support and was abandoned in June 1965, after only about 18 months of life.

The objections to the NILE project are similar to objections to preapprenticeship programs generally. Those who successfully completed the NILE program's requirements were assured of admission into apprenticeship. On the other hand, the general preapprenticeship program attempts

14 Final Report to the Secretary of Labor, United States Department of Labor on OMAT Project P-3-63, National Institute of Labor Education (July, 1963), p. 3.

15 Ibid., p. 66.

16 Ibid., pp. 65-68.

17 Ibid., p. 69. 
to upgrade the participants in order that they may compete with other applicants on a more equal basis. In these cases, however, there is no guarantee that the trainees will be admitted into apprenticeship. As for the content of the two types of undertakings, their substance is essentially the same. Both have sought to reach the group that is presently being bypassed by the skilled trades. However, our limited contact with these programs produced a more favorable evaluation. Our net impression of the programs in Washington, Cleveland, and Detroit is that they are an effective way both to provide opportunity to disadvantaged youths and to supply qualified applicants to apprentice programs. Even the most unsuccessful encountered, a NILE carpenters' program in Washington, was able to place 22 unemployed youths (20 Negroes) in the union's apprenticeship program.

\section{MDTA Programs}

As Table 1 shows, in the cities studied, there were 374 whites and 182 nonwhites (about 33 per cent) enrolled in MDTA institutional programs in July 1966. These programs were designed to upgrade the skills of the participants in order that they might compete for apprenticeship positions in the building trades on a more equitable basis. A number of other programs had been established which were not operational or about which there was no information in the Washington office of the Bureau of Employment Security. Of the nonwhite enrollees, 56 were in a virtually all nonwhite bricklayers program in Washington and another 62 were in a metal trades and painters apprentice programs in San Francisco-Oakland. Although there are not many nonwhites being trained in these programs, the proportion of nonwhites is obviously higher than the proportion of Negroes employed in skilled trades, and is higher than the rate of placement of MDTA trainees in all skilled trades during 1965.

\section{Workers Defense League}

A successful private undertaking is the Workers Defense League (WDL) in New York City. The WDL was founded prior to World War II as a privately operated human rights organization. Accordingly, it was concerned with the full array of civil rights issues until 1963 when demonstrations occurred in New York over the paucity of Negroes in the building crafts. After the demonstrations had succeeded in closing one municipal construction site, it became only too apparent to the civil rights leaders in general and to the WDL in particular that they had no way to supply applicants to apprenticeship programs even if they were accessible. Accordingly, the WDL decided to concentrate on the apprenticeship problem as one of 
TABLE 1

Approved MDTA (Institutional) Projects in Building

Trades in Selected Citues, July 1966

\begin{tabular}{|c|c|c|c|c|c|}
\hline Trade & Weeks & Provided for ${ }^{T}$ & Es Enrolled & White & Nonwhite \\
\hline \multicolumn{6}{|l|}{ Plumber } \\
\hline New York & 15 & $48^{\mathrm{a}}$ & NA & & \\
\hline New York & .... & 28 & 33 & 29 & 4 \\
\hline Subtotal & & & 33 & 29 & 4 \\
\hline \multicolumn{6}{|l|}{ Sheet metal } \\
\hline New York & 23 & $60^{\mathrm{a}}$ & NA & \multirow{4}{*}{15} & \multirow{4}{*}{22} \\
\hline Philadelphia & 48 & 24 & 37 & & \\
\hline Philadelphia (area) & 26 & $30^{\mathrm{a}}$ & NA & & \\
\hline Washington, D.C. (area) & 13 & $60^{\mathrm{t}}$ & NA & & \\
\hline Subtotal & & & & 15 & 22 \\
\hline \multicolumn{6}{|l|}{ Bricklayer } \\
\hline Detroit & 18 & 50 & 16 & 16 & 0 \\
\hline Detroit & 15 & 50 & 40 & 40 & 0 \\
\hline Detroit & 15 & $50^{\mathrm{a}}$ & NA & & \\
\hline Detroit & 21 & 96 & 125 & 117 & 8 \\
\hline Washington, D.C. (area) & 12 & 60 & 57 & 1 & 56 \\
\hline Washington, D.C. (area) & 12 & $60^{\mathrm{a}}$ & NA & & \\
\hline Washington, D.C. (area) & 12 & $120^{2}$ & NA & & \\
\hline Subtotal & & & & 174 & 64 \\
\hline \multicolumn{6}{|l|}{ Carpenter } \\
\hline San Francisco-Oakland & .... & $105^{a}$ & NA & \multirow{3}{*}{57} & \multirow{3}{*}{13} \\
\hline San Francisco-Oakland & 2 & 70 & & & \\
\hline San Francisco-Oakland & 6 & $180^{\mathrm{a}}$ & NA & & \\
\hline Subtotal & & & & 57 & 13 \\
\hline \multicolumn{6}{|l|}{ Ironworker-shop } \\
\hline Pittsburgh & 38 & & 36 & 29 & 7 \\
\hline Pittsburgh & 38 & & 28 & 18 & 10 \\
\hline Subtotal & & & & 47 & 17 \\
\hline \multicolumn{6}{|l|}{ Metal Trades Apprentice } \\
\hline San Francisco-Oakland & 13 & & 46 & 15 & 31 \\
\hline \multicolumn{6}{|l|}{ Painter } \\
\hline San Francisco-Oakland & 13 & $40^{\mathrm{a}}$ & & 24 & 16 \\
\hline San Francisco-Oakland & 13 & 28 & & 13 & 15 \\
\hline Subtotal & & & & & 31 \\
\hline Total & & & & 374 & 182 \\
\hline
\end{tabular}

SOURCE: U.S Department of Labor, Bureau of Employment Security.

a. Number provided in contract, actual enrollment unknown.

NA Not available.

its primary missions. It assumed the ambitious task of informing, recruiting, and preparing minority youth (Negroes and Puerto Ricans) for apprenticeship positions. ${ }^{18}$ With respect to preparation of applicants, the WDL has initiated a unique tutorial program. After screening its recruits through the use of an aptitude test (the Otis Quick Scoring Test of Mental AbilityGamma C), those selected are required to attend special two and a half hour

\footnotetext{
18 A detailed account of the WDL operations will be contained in our forthcoming book.
} 
sessions, three times a week, for up to two months prior to the date of the union's qualification examination. These "prep classes" are geared to testpassing rather than toward the Herculean job of providing general education. But, combined with instructions in how to take written and oral examinations, attention is given to reviewing basic mathematics, spatial relations, and practical reasoning.

Since 1963, the WDL has been directly responsible for the placement of over 175 minority youths into apprenticeship positions. Moreover, the vast preponderance of these placements have been in the electricians, sheet metal workers, plumbers, printers, and ironworkers crafts. The success of the WDL program stems from a variety of considerations, but two stand out as being especially prominent: (1) the WDL has sought to cooperate with the apprenticeship establishment in the city by learning the mystiques of the system and by avoiding whenever possible dramatic public confrontations that serve only to solidify intransigency to change; and (2) the success of the aforementioned tutorial program to upgrade the quality of its applicants.

The tutorial program has been especially successful with the WDL's applicants to the Sheet Metal Worker's program. The first Negro to be admitted to the local union was in the spring class of 1965. Twenty-eight Negro applicants were given a "crash review program" since there was less than two weeks notice given prior to the examination date. As a result, none of the 28 Negroes placed within the acceptable range of the top 65. But, because three whites in this group declined to accept positions in the class, the highest ranking Negro (the 68th in the ranking) was admitted. For the next class, the tutorial program was put into full-scale operation. The results for the fall 1965 class were that 12 of the WDL's 25 applicants placed within the top 65 and were accepted. Similarly, when the fall 1966 class was tested for admission, 24 of the WDL's 32 applicants placed within the cutoff range of 65 apprentices. In this last instance, the results were so astounding that the union went to court in January 1967 to protest the scores. The union contended that the scores were so high that they could only have been achieved by "some nefarious means." The lower court exonerated the WDL, but the union, as of this writing, plans to appeal the decision.

\section{Conclusions}

Sanctions have not been especially successful in getting Negroes into apprenticeship programs, though they have perhaps had the effect of creating a climate which is conducive to change, have tended to educate the parties concerned about apprenticeship and civil rights, have 
led to a formalization of apprentice standards and programs, and have caused some apprentice sponsors to raise their qualifications. While sanctions should be perfected, we must emphasize programs which increase the supply of qualified Negro applicants. If qualified applicants do not get in, then public policy will have to give greater emphasis to such sanctions as policing qualifications and testing systems.

The government has a major responsibility. It could certainly increase opportunities for minorities if measures were taken to raise the total number of apprentices. ${ }^{19}$ Much more needs to be known about apprenticeships first, however. It would be useful to know the answers to such questions as: What are the advantages and disadvantages of apprenticeship training as compared with other means of acquiring skills? What can the federal government do to ensure that training procedures are more realistic? To what extent should control of the apprenticeship system be left in private hands and to what extent should such matters as journeymen-apprenticeship ratios, training content, length of training, and testing and selection procedures be regulated?20 These questions should be answered before policies are adopted to increase the participation of Negroes or other groups. In other words, if we are going to expend resources getting people into these programs, we must convince ourselves that this is training which should be expanded. Because, of course, if it is not, we are getting Negroes and other youngsters ready for positions which do not exist. ${ }^{21}$

Besides clarifying the issues through effective research and debate and establishing policies, the federal government can do many things to promote apprenticeship opportunities for Negroes. It can, for example, work to overcome the resentment and defensiveness of the apprenticeship establishment and take measures to strengthen the industrial training advisers, the apprenticeship information centers, and preapprenticeship training programs.

We are particularly convinced that the federal government should give financial support to various private organizations, like the Workers Defense League program in New York. Such private organizations have a significant

19 There are about 50,000 apprenticeship openings each year and the dropout rate is about 50 per cent; therefore, about 25,000 craftsmen enter the labor market annually through apprenticeship training, and many apparently go into supervisory and managerial positions. With a great deal of effort, it might be possible to increase the Negro proportion of new apprentices to 15 per cent; this would provide perhaps 7,500 openings a year and 3,750 graduates a year, unless something is done to reduce the dropout rate.

20 Although we do not feel competent to evaluate the relevance of tests, qualifications, and the length of training, many of our interviewees expressed grave doubts about these matters. Also, the diversity of journeymen-apprentice markets would make it unwise to establish national standards.

21 It would be useful to know how many trainable Negro youngsters are likely to choose the skilled trades after apprenticeship training is explained to them in realistic terms. 
advantage over government agencies in being able to avoid political control and interagency rivalries. Both private and public financing might give these organizations more stability and permanence than is sometimes possible with federal programs. Such agencies can provide accurate information concerning apprenticeship programs and can recruit Negro youngsters who are qualified for apprenticeship or who are amenable to tutoring and other programs to overcome their deficiencies. These apprenticeship organizations would be invaluable to minority youngsters whose parents do not understand the apprentice system or do not have time to provide the detailed support and encouragement necessary to get minority youngsters through all of the complex admission procedures.

Remedial organizations must have the cooperation of apprenticeship sponsors as well as minority organizations, of course. The organization certainly would be expected to protect the minority applicant by pressing legitimate charges of discrimination against apprentice sponsors, but it should take this action only after careful investigation. Cooperation would be most effective where minority group organizations render a service to apprenticeship sponsors in return for their help.

The major functions of remedial organizations might include the referral of only qualified applicants who would improve or maintain prevailing apprentice and journeymen standards, protection of apprentice sponsors from unfair charges of discrimination, explaining to minority youths the legitimate reasons for their rejection from apprentice programs, and gaining minority support for the political and legislative objectives of apprentice sponsors.

It is obvious that the program we have outlined requires the cooperation and sometimes the conflict of unions, employers, civil rights groups, and government agencies. But we have some evidence, especially from the Workers Defense League project in New York City, that such a program is likely to be successful in getting minority youngsters into good training programs. We also are persuaded that these kinds of organizations are essential to break the system which has separated minority youngsters from the channels leading to better jobs. 